No 2008 - 10

June

\title{
CEPII
}

Cax rex

-

ET D'INFOEMATIONS

INTERNATIONALE

\section{International Trade Price Indices}

Guillaume Gaulier

Julien Martin

I sabelle Méjean

Soledad Zignago 


\section{International Trade Price Indices}

Guillaume Gaulier Julien Martin

Isabelle Méjean

Soledad Zignago

No $2008-10$

June 


\section{Contents}

$\begin{array}{lll}1 & \text { Introduction } & 9\end{array}$

2 Index Numbers: a Theoretical Tale $\quad 11$

2.1 Laspeyres and Paasche Indices . . . . . . . . . . . . . . . . . . 11

2.2 Chained Indices . . . . . . . . . . . . . . . . . . . . . . . . . . . . . . 13

2.3 Composed Indices . . . . . . . . . . . . . . . . . . . . . . . . . . . . 14

2.4 Exact and Superlative Indices . . . . . . . . . . . . . . . . . . . . . . . . . 15

3 Data and Outliers Management 16

3.1 Data: BACI unit values $\ldots \ldots \ldots \ldots$

$3.2 \quad$ Methodology for Outliers . . . . . . . . . . . . . . . . . . . 18

3.3 Unit Values Aggregation on Different Data Dimensions . . . . . . . . . . . . 21

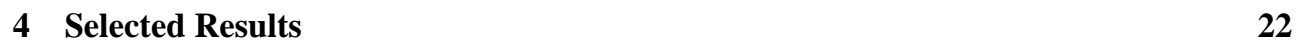

$4.1 \quad$ Comparison between Indices $\ldots \ldots \ldots \ldots$. . . . . . . . . . . . . . 22

4.2 Export Prices in Developed Countries . . . . . . . . . . . . . . . . . . . . 26

4.3 Terms-of-Trade in Emerging Countries . . . . . . . . . . . . . . . . . . . . 31

$4.4 \quad$ International Trade Values and Volumes $\ldots \ldots \ldots$. . . . . . . . . . . . . 34

5 Concluding Remarks 36

\begin{tabular}{|lr}
\hline A Appendices & 38
\end{tabular}

A.1 Desirable mathematical properties of price indices . . . . . . . . . . . 38

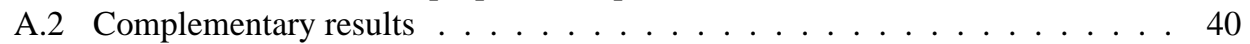


International Trade Price Indices

International Trade Price Indices

\section{NON-TECHNICAL SUMmaRY}

Export and import price indices are useful instruments in international economics. International trade theory shows that relative prices determine industrial specialization and welfare gains resulting from trade openness. Hence, the evolution of international trade prices is a source of ceaseless debates such as the consequence of trade policies, the quality and cost competitiveness of countries, or the influence of globalization on worldwide inflation. More precisely, international macroeconomics analysis requires trade prices indices to study terms of trade, inflation or volume/price elasticity of open economies. In international trade studies, price indices allow for instance to deflate trade values in order to obtain volumes.

The methodology used by national statistical institutions to compute price indices often differs and prevents any type of cross-country analysis. For instance, the American Bureau of Labor Statistics gives Laspeyres type indices of US exports and imports observed prices, whereas the French national statistical institute, the INSEE, provides Paasche type indices built on French external trade unit values. Of course, the UN and the IMF provide crosscountry comparable price indices, releasing export and import unit value indices at an aggregate level, but their series have some limitations. Firstly, they report only Laspeyres indices which are not necessarily the most appropriate (for instance, they can over-estimate the actual price changes). Secondly, the data cover only 44 countries, excluding many developing countries. Finally, there are no disaggregated trade indices making large scale and detailed international comparison possible.

This work aims at providing aggregated and sectoral trade price indices for practically all countries of the world. These indices are computed using unit values given by BACI, the CEPII's database of international trade at the product-level. BACI provides value, quantity and unit values of world bilateral flows. It covers the period 1995-2004 and its rich country dimension is particularly useful for international comparison of prices evolutions. The resulting TradePrices database is available on line at BACI's CEPII web page, offers to users the possibility to choose the most accurate index for each particular purpose. In addition, the SAS programs are also downloadable making our trade price indices transparent and flexible. Several formulas are used, namely the common Laspeyres and Paasche indices but also "superlative" Fisher and Tornqvist indices, in both chained and fixed-base forms. The chained Laspeyres and Paasche are also calculated in their geometric form.

In the first part of this paper we present the formulas of the different indices that we compute. Relying on existing literature (particularly Diewert (1976) and Feenstra (2004)), we present the characteristics of these different aggregation methods. In particular, we highlight the links existing between statistical methods and economical assumptions about implicit elasticity of 
substitution between goods. Indeed, for example, the Tornqvist index can be derived from a translog utility function assuming a peculiar elasticity of substitution between goods. An exhaustive sensitivity analysis is done in order to determine the appropriate way to deal with technical difficulties, such as the treatment of measurement errors in bilateral unit values.

After describing the methodology used, this paper provides some stylized facts illustrating our results. From a statistical point of view, we highlight that the aggregation method to compute trade price indices matters and that international comparisons of trade price indices need to use indices computed with the same formula. That strengthens the necessity to provide a trade price database allowing international comparison. From an economic point of view, we show, with some selected results, the usefulness of both aggregated and sectoral trade price indices to study international economics. Thus, for instance, French and German export prices evolution cannot explain the lack of competitiveness of French exporters. We observe also that the BRIC (Brazil, Russia, India and China) experience different evolution of their terms of trade. A sectoral analysis allows us to understand the determinants of these differences. Russia for example, experiences an appreciation of its terms of trade due to the boom of primary good prices, which are an important share of its exports (particularly gas). Lastly, we use our price indices to deflate international trade values data in order to get volume series. Whereas the trade of primary goods experiences the largest growth in value in 2003 and 2004, the sector in which traded volumes increased the most in 2003-2004 concerns the investment goods.

\begin{abstract}
Export and import price indices are useful instruments in international economics. We document here TradePrices, our database of aggregated and sectoral trade price indices for all countries, computed using unit values given by BACI, the CEPII's database of international trade at the product-level covering the period 1995-2004. Its rich country dimension allow an international comparison of prices evolutions. We compute "common" Laspeyres and Paasche indices but also "superlative" Fisher and Tornqvist indices, in both chained and fixed-base forms (chained Laspeyres and Paasche are also provided in their geometric form). In a first part, we discuss the characteristics of these different aggregation methods. In particular, we highlight the links between statistical methods and economical assumptions about implicit elasticity of substitution between goods. In a second step we describe the data. An exhaustive sensitivity analysis is done in order to determine the appropriate way to deal with technical difficulties, such as the treatment of measurement errors in bilateral unit values. Finally, this paper provides some stylized facts illustrating the necessity to provide a trade price database allowing international comparison and the usefulness of both aggregated and sectoral trade price indices to study international economics. TradePrices database and
\end{abstract}


SAS programs are freely available online, offering to users the possibility to choose the most accurate index for each particular purpose.

JEL classification: F12, F15

Key words: International Trade, Price indices. 
CEPII, Working Paper. No 2008-10

\section{Indices DE Prix DU COMMERCE INTERnATIONAL}

\section{RÉSUMÉ NON-TECHNIQUE}

Les indices de prix du commerce international sont une ressource utile en économie internationale. Les théories du commerce international montrent que les prix relatifs déterminent la spécialisation industrielle et les gains associés à l'ouverture au commerce. L'évolution des prix internationaux fait dès lors l'objet d'incessants débats portant sur l'impact des politiques commerciales, de la compétitivité-coût, de la qualité ou, plus généralement, de la mondialisation sur l'inflation mondiale. Plus précisément, en macroéconomie internationale ces indices permettent d'étudier les termes de l'échange, les élasticités de substitution volume/prix, ou encore, l'impact des importations sur l'inflation domestique. Ils peuvent aussi être utilisés pour déflater les données en valeur des échanges internationaux et ainsi obtenir des volumes. Différentes méthodes de calcul de ces indices sont utilisées par les instituts statistiques nationaux, ce qui empêche des comparaisons internationales. Les Nations-Unies et le FMI proposent des indices comparables mais sans détail sectoriel et seulement pour un nombre assez limité de pays, laissant de côté bon nombre de pays en développement.

Nous proposons une nouvelle base de données d'indices de prix du commerce international, TradePrices, construite à partir de BACI, la nouvelle base du CEPII d'échanges internationaux de produits (plus de 5000). BACI fournit la valeur, la quantité et la valeur unitaire de chaque flux bilatéral, pour 200 pays sur la période 1995-2004. Nos indices sont calculés aux niveaux agrégé et sectoriel à partir de différentes formules : Paasche, Laspeyres, Tornqvist et Fisher, dans leur version chaînée ou non-chaînée. Cette base ainsi que les programmes utilisés sont disponibles sur notre page :

www.cepii.fr/anglaisgraph/bdd/baci/non_restrict/price.asp

Dans cet article, nous exposons dans un premier temps les caractéristiques des indices de prix. En nous appuyant sur les travaux de Diewert (1976) et Feenstra (2004), nous rappelons les fondements théoriques des différentes formules statistiques permettant de mesurer l'évolution des prix. Nous détaillons ensuite les données et la méthodologie utilisée pour éliminer les valeurs aberrantes. En effet, pour calculer nos indices nous utilisons les valeurs unitaires de BACI comme approximation des prix. Cette approximation présente plusieurs problèmes mais : i) c'est la seule source d'information disponible au niveau international, ii) la forte désagrégation des données et l'harmonisation des valeurs unitaires de BACI les limitent, iii) nous apportons un soin particulier au traitement des données aberrantes.

Enfin, la dernière partie propose une sélection de résultats. D'un point de vue statistique, ces résultats mettent en évidence les différences entre indices et confirment l'importance d'une base permettant les comparaisons internationales. Nous présentons ensuite quelques faits stylisés illustrant l'intérêt de notre base pour l'analyse économique. Nous montrons par exemple 
que les différences de performances à l'exportation de la France et de l'Allemagne ne peuvent s'expliquer par des différences dans l'évolution des prix à l'export des deux pays. Nous nous intéressons aussi à l'évolution des termes de l'échange des principaux pays émergents. Enfin, nos indices sont utilisés pour déflater les échanges en valeur afin d'étudier la dynamique en volume du commerce mondial.

\section{RÉSUMÉ COURT}

Les indices de prix du commerce international sont une ressource utile pour l'analyse économique. Nous proposons une nouvelle base de données d'indices de prix du commerce international, TradePrices, construite à partir des valeurs unitaires de BACI, la base du CEPII couvrant les flux internationaux de biens au niveau le plus fin de désagrégation (plus de 5000 produits), pour 200 pays sur la période 1995-2004. Plusieurs indices sont calculés au niveau agrégé mais aussi sectoriel : Laspeyres, Paasche, Fisher et Tornqvist, dans leur version chânée ou non-chaînée. Nous présentons d'abord les propriétés des différents indices de prix. L'accent est mis sur les liens existant entre les formules statistiques et les hypothèses microéconomiques sous-jacentes concernant l'élasticité de substitution des biens. Nous décrivons ensuite les données et la méthodologie retenue pour traiter les valeurs unitaires aberrantes. Enfin, nous proposons différents faits stylisés illustrant l'utilité de cette base pour l'étude du commerce international. La base TradePrices, ainsi que les programmes utilisés pour la construire, sont disponibles en ligne, donnant aux utilisateurs la possibilité d'adapter la méthode à la problématique qu'ils souhaitent étudier.

JEL classification : F12, F15

Mots Clefs : Commerce international, Indices de prix, Volumes 


\title{
International Trade Price Indices]
}

\author{
Guillaume GAULIER ${ }^{2}$ \\ Julien MARTIN ${ }^{3}$ \\ Isabelle MEJEAN ${ }^{4}$ \\ Soledad ZIGNAGO
}

\section{Introduction}

Export and import price indices are useful tools in international economics. In open macroeconomics, they allow to study the influence of globalization on worldwide inflation, the international transmission of shocks and the sensitivity of trade imbalances to prices and exchange rate adjustments. In international trade, relative prices determine industrial specialization and welfare gains resulting from trade openness. They are used to analyze the terms of trade and changes in traded volumes. While this information is central in economic theory, price indices are difficult to find in existing databases, in particular for less developed countries.

Our new TradePrices database aims at filling this gap by providing international trade price indices computed using unit values from BACI, the CEPII database describing international trade flows at the product level (the 5,000 items of the Harmonized System) during the 19952004 period ${ }^{6}$ The exhaustive country coverage of BACI allows us to compare price evolutions across countries. The comparison is not always possible using existing series of trade price indices because of methodological discrepancies. As national statistical institutes do not use the same methodology to compute price indices, cross-country analysis may be biased. For instance, the US Bureau of Labor Statistics computes Laspeyres type indices aggregating observed prices of US trade flows. On the other hand, the French national statistical institute provides Paasche type indices based on unit values. Trying to compare trade prices using these sources of information is tricky as observed discrepancies can have economic or

We appreciate the helpful suggestions of Agnès Benassy-Quéré and Matthieu Crozet. We are also grateful to participants at the CEPII lunch seminar for their comments.

${ }^{2}$ Banque de France.

${ }^{3}$ CEPII, Paris1-PSE (baci@ cepii.fr).

${ }^{4}$ Ecole Polytechnique.

${ }^{5}$ CEPII.

${ }^{6}$ See http://www.cepii.fr/anglaisgraph/bdd/baci.htm 
methodological sources. Another solution is to use trade prices built by international institutions. Both the IMF and the United Nations provide cross-country comparable Laspeyres price indices aggregating export and import unit values. The country coverage of their databases is however limited to 44 countries and many developing countries are ignored.

Beyond a large country coverage, our TradePrices database tries to provide the user with the maximum degree of flexibility. Firstly, one can choose between several aggregation methods. This is in sharp contrast with existing databases that propose a single type of price indices, generally Laspeyres. This method is the most commonly used but not necessary the best measure of prices because this index is not superlative, as we will explain. On the contrary, our database lets the user with the choice between Laspeyres, Paasche, Tornqvist and Fisher price indices, either in their fixed or in their chained form. While Tornqvist and Fisher price indices can be considered as "better" measures of price evolutions (in the sense that they are "superlative" indices), the user may prefer working on price series that aggregate unit values using a weighting scheme based on a single reference period. Moreover, the comparison between different types of price indices can be instructive in itself, for instance to investigate the price impact of substitution among goods in response to nominal shocks.

Another advantage of the TradePrices dataset is that price series are not only provided at the aggregate level but also at the sectoral level: we provide price evolutions for 205 countries and for 40 sectors of the ISIC revision 2 classification. The SAS programs however allows the user to adapt the aggregation level and product classification to his own purpose. To our knowledge, this is the first database providing sectoral trade price indices for a large panel of countries. Datasets and programs are posted at:

www.cepii.fr/anglaisgraph/bdd/baci/non_restrict/price.asp

Our series are not devoided of drawbacks. An important caveat is that trade prices are approximated by unit values, measured at the 6-digit level of the Harmonized System. Using unit values as proxies for prices is well-known to generate measurement bias, even at a fine level of aggregation. In particular, it is difficult to distinguish price from quality changes in such series. As this is the only source of information available on a worldwide basis, we nevertheless use unit values. However, we pay a particular attention to the question of outliers. Detection of outliers is a critical point of the construction of unit value indices (see Silver (2007)). A methodology is developed to drop outliers, keeping a maximum volume of information.

The rest of the paper is organized as follows. Section 2 considers the theoretical concepts underlying price index formulas. Section 3 presents the BACI database and describes our treatment of outliers. Section 4 provides empirical results illustrating some theoretical points about index numbers underlined in the first section. Moreover, we give some examples of the kind of results that can be inferred from the cross-country and cross-sector comparison of our price indices. Finally, the last section concludes. 


\section{Index Numbers: a Theoretical Tale}

A survey conducted by the United Nations Statistical Division about national practices in compilation and dissemination of external trade index numbers (UNSD (2005)) shows that indices used by national statistical institutes are Laspeyres, Paasche or Fisher indices, either fixed-base or chained. No consensus arises from this survey about the "good" way to aggregate prices. Our trade price database provides a large set of indices. None is perfect, but each one has its own advantages. This multiplicity of indices lets the user with the choice to get the more convenient one with respect to his own purpose. In this section, the different trade price indices and some of their features are presented.

\subsection{Laspeyres and Paasche Indices}

In the literature on trade price indices, two commonly used index formulas are the Paasche and Laspeyres indices. Both measure the price evolution of a given basket of goods, between a reference and the current periods. Their computation extracts price changes by controlling for variations in traded quantities. The difference between both formulas is that the Laspeyres index measures the price variation of the basket of goods consumed in the reference period while the Paasche index weights prices by current quantities. Note that the choice of the reference year affects measured price evolutions as the fixed price and possibly the weighting scheme are conditional on the chosen reference year 7

The Laspeyres unit value index is built as an arithmetic average of unit value ratios, $p_{k, t} / p_{k, 0}$, weighted by the share of each good in the traded value of the reference period $\left(w_{k, 0}\right)$ :

$$
L_{t / 0}=\frac{\sum_{k} p_{k, t} q_{k, 0}}{\sum_{k} p_{k, 0} q_{k, 0}}=\sum_{k} w_{k, 0} \frac{p_{k, t}}{p_{k, 0}}
$$

where $w_{k, 0}=\frac{p_{k, 0} q_{k, 0}}{\sum_{k} p_{k, 0} q_{k, 0}}=\frac{v_{k, 0}}{\sum_{k} v_{k, 0}}$. In this expression, $k$ denotes a good, $p_{k, t}$ its price in period $t, q_{k, t}$ the traded quantity and $v_{k, t} \equiv p_{k, t} q_{k, t}$ the value of the flow ${ }^{8}$ The price ratio $p_{k, t} / p_{k, 0}$ thus measures the price variation of the good $k$ between periods 0 and $t$.

\footnotetext{
${ }^{7}$ The reference year is used as the comparison point for price evolutions in fixed-base index formulas. Price indices computed using these formulas thus measure price evolutions with respect to the reference year and are sensitive to the choice of this reference point. In contrast, the choice of the base year does not impact measured price variations (for the base year, which is 2000 in this paper, the index is equal to 100$)$.

${ }^{8}$ In this section, the good and its producer are not explicitly differentiated. However, one can consider that $k$ denotes a particular good produced in a single country/imported by a specific market. See details in section 3
} 
Contrasting with the Laspeyres index, the Paasche index aggregates price changes using current period weights. It thus better captures changes in the structure of trade. It is an harmonic average of elementary indices weighted by the share of each product in the current traded value:

$$
P_{t / 0}=\frac{\sum_{k} p_{k, t} q_{k, t}}{\sum_{k} p_{k, 0} q_{k, t}}=1 / \sum_{k} w_{k, t} \frac{p_{k, 0}}{p_{k, t}}
$$

where $w_{k, t}=\frac{p_{k, t} q_{k, t}}{\sum_{k} p_{k, t} q_{k, t}}$ is the weight of good $k$ in period $t$.

Both indices measure effective price evolutions with a systematic error for two main reasons. A first source of bias is linked to the fact that these indices measure price evolutions between two years using a weighting scheme based on the structure of trade in a single year, avoiding to take into account any substitution effect ${ }^{9}$ The Laspeyres index, because it uses the weight matrix in the reference year, tends to overestimate real price evolutions: When prices rise, consumers tend to substitute their consumption towards relatively cheaper goods (reducing thus the quantities consumed at the end of the period). Said otherwise, the Laspeyres index reflects a world without substitution effects and consequently overrates true price growth. Conversely, the Paasche index tends to underestimate price evolutions by attributing a larger weight to products that have been increasingly consumed following a relative price drop. One can thus expect the Laspeyres price to exceed the Paasche. As Feenstra (2004) explains in his appendix on indices, this "Gershenkron effect", has been tested empirically by different authors, datasets and periods. We test also the presence of a Gershenkron effect in our section 4.

Aggregating prices using a geometric rather than an arithmetic mean is a first way to deal with substitution effects. The geometric mean implies a unitary elasticity of substitution between products. For most goods, this is probably a more sensible hypothesis than the absence of substitution implicitly assumed in simple Laspeyres and Paasche indices. The formulas for the geometric Laspeyres (3) and Paasche (4) indices are the following:

$$
\begin{aligned}
& g L_{t / 0}=\prod_{k}\left(\frac{p_{k, t}}{p_{k, 0}}\right)^{w_{k, 0}} \\
& g P_{t / 0}=\prod_{k}\left(\frac{p_{k, t}}{p_{k, 0}}\right)^{w_{k, t}}
\end{aligned}
$$

The statistical properties of averages imply that the Laspeyres index always exceeds the geometric Laspeyres index while the geometric Paasche index always exceeds the simple Paasche index.

\footnotetext{
${ }^{9}$ Whereas the superlative indices consider an elasticity of substitution as explained in section 2.4
} 
CEPII, Working Paper. No 2008-10

A second source of measurement error is linked to extensive margin effects. Both the Laspeyres and Paasche indices neglect changes in the supply of traded varieties due to the appearance/disappearance of products between the reference and the current periods. These extensive margin effects have yet been shown to affect price evolution through two channels. First, when omitting goods in the computation of price evolution one loses a lot of information particularly if the new goods have a large share in the consumption. A famous example of omitted good is the computer which is claimed by the Boskin Commission to be everywhere except in the statistics. The second channel is developed theoretically by Feenstra (1994) and Broda \& Weinstein (2006). These authors show that if preferences have a CES form, the appearance of a new variety means that the price of this variety decreases from infinite to the observed price. Not taking into account the new products leads to overestimate the price evolution. Broda \& Weinstein (2006), using US data, and Gaulier \& Mejean (2006), using BACI data, find empirical evidences of this phenomenon.

In a nutshell, geometric indices allow substitution between goods which probably increases the accuracy of measured price evolutions, even if the unitary elasticity is still a restrictive assumption. However, fixed-base indices do not account for extensive margin effects. When dealing with changes in the structure of trade, it is probably better to use chained indices.

\subsection{Chained Indices}

With chained indices, the reference period varies over time. This allows to account for changes in the composition of traded baskets of goods, as reflected by variations in the weight of each product entering the consumption basket. Chained indices also capture changes in the array of traded goods, though with a lag. A product appearing on period $t$ will be integrated in the index on period $t+1$, while it was neglected by the fixed-base index. Chained Paasche and Laspeyres indices are constructed as follows:

$$
\begin{aligned}
& c L_{t}=\prod_{i=1}^{t} L_{i / i-1} \\
& c P_{t}=\prod_{i=1}^{t} P_{i / i-1}
\end{aligned}
$$

where $L_{i / i-1}\left(P_{i / i-1}\right)$ is the basic Laspeyres (Paasche) index with a reference year in $i-$ 1. The choice between chained and fixed-base indices is an important practical question. Chained indices are source of higher precision. However, if the series are highly volatile, chained indices should be avoided because they induce a drift in measured price series. As 
discussed in Feenstra \& Shapiro (2001) and Berthier (2003), this type of indices accumulates the information from period to period; any peak in the data will be retained in the index. In our database, the covered period is short, which de facto limits the drift. However, some countries have steady price variations. A first solution to limit this problem is to chain geometric rather than simple indices, that give more weight on extreme values. Chained geometric indices are constructed as follows:

$$
\begin{aligned}
& c g L_{t}=\prod_{i=1}^{t} g L_{i / i-1} \\
& c g P_{t}=\prod_{i=1}^{t} g P_{i / i-1}
\end{aligned}
$$

where $g L_{i / i-1}\left(g P_{i / i-1}\right)$ is the geometric Laspeyres (Paasche) index with a reference year in $i-1$.

\subsection{Composed Indices}

As explained above, while the previous methods help treating problems related to changes in the consumption structure, all the indices still suffer from measurement bias, related to the fact they use the information of a single period as weights to aggregate elementary indices. In connection with this, composed indices are richer as they use in a symmetrical way the information on quantities traded in the two observation periods. Moreover, the combination of Paasche or Laspeyres indices leads to indices that implicitly assume a substitution elasticity between zero and one. Empirically, it has been shown that the Laspeyres and Paasche indices are upper and lower bounds of the real price evolution (Feenstra (1997)). Computing a geometric mean of these indices (i.e. building a Fisher index) is a good way to approach this (unobserved) real price index. This aggregation can also be done with the geometric Paasche and Laspeyres indices, which corresponds to a Tornqvist index. This index has been shown to have convenient empirical properties as well Diewert (1976). The Fisher $(F)$ and Tornqvist $(T)$ indices are defined as 10

$$
F_{t / 0}=\left(P_{t / 0} \cdot L_{t / 0}\right)^{1 / 2}
$$

\footnotetext{
${ }^{10}$ The Tornqvist index $\sqrt{10}$ can be rewritten as $T_{t}=\prod_{k}\left(\frac{p_{k, t}}{p_{k, 0}}\right)^{\left(w_{k, 0}+w_{k, t}\right) / 2}$. This formulation shows that this index is a geometric average of price ratios, weighted by the mean traded quantities in both periods.
} 


$$
T_{t / 0}=\left(g P_{t / 0} . g L_{t / 0}\right)^{1 / 2}
$$

One can chain the composed indices as well:

$$
\begin{gathered}
c F_{t}=\left(c P_{t} \cdot c L_{t}\right)^{1 / 2} \\
T_{t}=\left(c g P_{t} \cdot c g L_{t}\right)^{1 / 2}
\end{gathered}
$$

Diewert (1976) uses a Fisher test to compare different price indices and proves the superiority of Fisher and Tornqvist indices on Laspeyres and Paasche formulas ${ }^{11}$ But to further prove the relevance of these two indices, Allen \& Diewert (1981) develops an approach that helps choosing the best price index formula adapted to the underlying economic model.

\subsection{Exact and Superlative Indices}

Two types of economical functions imply a relation between trade prices and consumed quantities: cost and utility functions. Depending on the underlying model, trade price indices can be considered as the empirical counterpart of the cost minimizing function of a representative firm importing inputs from abroad or the utility maximizing function of a representative household consuming foreign goods. The exact form of the price index depends on the functional form. In the following, we focus on utility functions but developments with cost functions are symmetric.

Consider a utility function: $u\left(p_{t}, R\right)$ where $p_{t}$ stands for the vector of prices of the goods at the date $t$. The associated ideal (or theoretical) price index relative to Year 0 is:

$$
P\left(p_{0}, p_{1}, R\right)=u\left(p_{1}, R\right) / u\left(p_{0}, R\right)
$$

It is a Constant Utility Index (CUI) measuring the variation in nominal income $(R)$ necessary to maintain the same utility given observed price changes between periods 0 and 1 . The particularity of this index is that it depends on prices and quantities but also on the form of the utility function. Diewert calls "exact" an index equal to the ideal index of a specific utility function. For instance, the exact index associated with a Leontief function is the Laspeyres or the Paasche index ${ }^{12}$ In the case of a Cobb-Douglas function, the exact index is the geometric index, which assumes a unitary elasticity of substitution. If consumer preferences can be represented by a quadratic function, then the exact index is the Fisher one. Furthermore, the

\footnotetext{
${ }^{11}$ See details on Appendix A concerning Fisher (1922) test on the accuracy of various price index formulas.

${ }^{12}$ In the case of Leontief function, goods are assumed complementary and the share of each good in the consumption is fixed. As a consequence, the empirical weights measured at the reference or current period are the same and the Paasche and Laspeyres indices are strictly equivalent.
} 
International Trade Price Indices

Fisher index is flexible itself, i.e. it is capable of providing a second order approximation to an arbitrary twice differentiable linearly homogeneous function. In other words, the Fisher index is exact for a quadratic utility function and is a good approximation of a large set of other ideal indices. For this reason, the Fisher index is said superlative. The Tornqvist index is superlative as well. It is exact for the translog function and it is flexible itself. The main characteristic of the translog function is that the conditional demand functions are not linear vis-à-vis the parameters. Contrary to an homothetic function, the substitution elasticity between goods $\mathrm{A}$ and $\mathrm{B}$ is not necessarily the same than between goods $\mathrm{A}$ and $\mathrm{C}{ }^{13}$ For this reason, one can consider the Tornqvist index to be the best approximation of price variations, from a theoretical viewpoint ${ }^{14}$ Empirically, Fisher and Tornqvist indices however provide close results.

Depending on the underlying model, the researcher can be brought to favor one of the previously described price index formulas. This justifies providing the user with different price series. Moreover, the comparison of indices can be instructive in itself. The gap between two specific indices can reveal interesting things about the price impact of some structural changes. For instance, comparing an index taking into account new products with another computed from a fixed array of traded goods can provide insights on the quantitative impact of extensive margin effects on price evolutions. Our TradePrices database provides 10 different series of price indices, 6 fixed-base price series, alternatively computed using a Laspeyres, a geometric Laspeyres, a Paasche, a geometric Paasche, a Fisher and a Tornqvist formula, as well as 4 chained indices, the geometric Laspeyres, the Paasche, the Fisher and the Tornqvist ones. The following section describes the data used to obtain these series.

\section{Data and Outliers Management}

\subsection{Data: BACI unit values}

In order to exhaustively measure international price variations, we use BACI, the database describing international trade flows at the sectoral level developed by Gaulier, Paillacar \& Zignago (2008). BACI covers about 200 countries and 5, 000 products over the 1995-2004 period. It draws on the United Nations' COMTRADE database and reconciles the declarations of trading partners to obtain harmonized data. For each product $k$, exported from

\footnotetext{
${ }^{13} \mathrm{~A}$ demand function is called homothetic if it is derived from homothetic preferences. Homothetic preferences assure that consumers with different incomes but facing the same price will demand goods in the same proportion.

${ }^{14}$ This theoretical approach considers two periods but indices are interesting as time series. If the Tornqvist index turns out to be a good approximation of price evolutions between two periods, the chained Tornqvist can be considered as a good index to measure price evolution over several periods.
} 
country $i$ to country $j$ in year $t$, BACI provides the value $\left(v_{i j k t}\right)$, quantity $\left(q_{i j k t}\right)$ and unit value $\left(p_{i j k t}\right)$ of the flow. Nominal variables are proposed in current US dollars and quantities are in tons.

The main advantage of this database is its high disaggregation level. BACI products are defined at the 6-digit level of the Harmonized System (HS6 in the following). This allows assimilating prices to unit values, defined as the ratio of value over quantity, using either the harmonized or the crude data ${ }^{15}$ However we are aware of the limits of this approximation. Even at the HS6 level, unit values are well-known to be a biased measure of prices, as underlined by Kravis \& Lipsey (1974) and Silver (2007) among others.

Silver (2007) discusses the magnitude and origin of the gap between unit value and price indices. He highlights several problems associated with unit value indices. The detection and deletion of outliers can eliminate too many observations, particularly large price evolutions ${ }^{16}$ To limit this problem we develop in section 3.2 a specific method that conserves more than 70 percent of the world trade value. The problem linked with information on quantities is also highlighted by Silver. To treat this problem, BACI is a convenient source of information as data on quantities are harmonized and converted in tons using an original method. Compositional changes in quantities and quality mix are a real problem in the construction of unit value indices, particularly because the considered products are not totally homogeneous. Of course, this problem is limited when using disaggregated data as is the case with our database that covers more than 5,000 product categories. However, as Silver makes it clear, the homogeneity assumption is still far from being verified at this aggregation level for some highly differentiated products. Though aware of this problem, we nevertheless use unit values as proxy for prices, as it is the only information on bilateral trade prices available with a large country coverage at the product level ${ }^{17}$

To show that unit values can be good proxy for prices, at least for homogeneous enough goods, we have compared our results with existing series of "true" price indices. Figure 1

\footnotetext{
${ }^{15}$ In the BACI database, $v$ and $q$ are the harmonized values and quantities that reconcile the declarations of both partners. It can be the case, however, that only the value can be harmonized because one country does not declare any quantity. In this case, the harmonized unit value is not the ratio of the harmonized value over the non-harmonized quantity but the ratio value/quantity as declared by the country providing both pieces of information.

${ }^{16}$ Silver gives as an example Alterman (1991) who has to keep only $44 \%$ of the import value and $54 \%$ of the export value to get rid of outliers from the distribution of unit values he uses to build price indices.

${ }^{17}$ Note that the discrepancies between unit value and price indices discussed in Silver (2007) are not necessarily entirely attributable to measurement bias in unit values. His comparison concerns indices computed using different formulas. Yet, it is shown theoretically and empirically in this paper that using different formulas is a source of discrepancies in price index series.
} 
and Table A.2 illustrate together the world price evolution of crude petroleum, computed from BACI at the HS4 level, and a price index calculated with observed prices of the Crude, which is a composite price of different crude petroleums, computed by the IMF (Source: International Financial Statistics.). Figure 1 puts in evidence a very similar trend in the behavior of both series, which is confirmed by the yearly variations displayed in Table A.2 of the Appendix A.2

Figure 1: Comparison of observed prices and unit value index for Crude

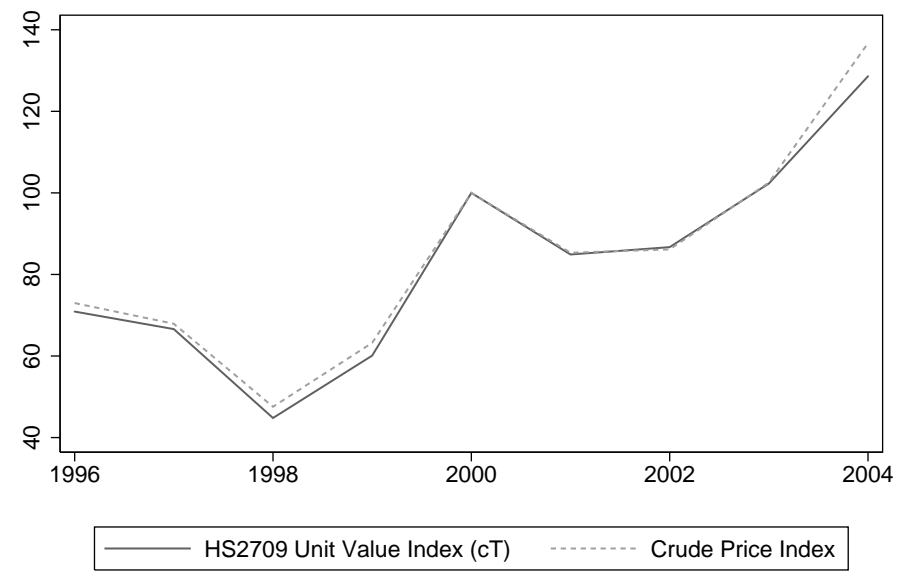

Source: IFS for observed Crude prices and BACI for the unit values of the HS section 2709 (petroleum oils, oils from bituminous minerals, crude). Chained Tornqvist index, base year: 2000 .

As explained in Silver (2007), the problem of outliers is particularly prevalent when computing unit value indices. For instance, the price index we obtained using all the information on French exports recorded in BACI suggests that prices were divided by 10 between 1998 and 2000. This kind of unrealistic result pushed us to develop a methodology to eliminate outliers.

\subsection{Methodology for Outliers}

A thorough study of our data reveals that a few outliers are the cause of a lot of damages. We call outlier an "unrealistic" price growth in the product-specific distribution of unit value 
ratios, measured as $p_{i j k t} / p_{i j k 0}$ for fixed-base indices or as $p_{i j k t} / p_{i j k t-1}$ for chained indices. Over the 1995-2004 period, the average unit value variation is higher than the 95 percentile of the product-specific distribution of unit value variation for 2015 of the 5017 products registered in BACI. This means that the average is largely impacted by the the highest $5 \%$ of the distribution. Still, the median unit value variation for all the products is close to one and the standard deviation of these medians over products is very low (0.022). The huge gap between the median and the average of unit value variations reflects the large impact of outliers.

A first source of outliers is the presence of misleading trade flow reports. For instance, national customs do not have the same reporting threshold. As a consequence, values and quantities reported at the minimum level (respectively one thousand dollars and one ton in BACI) may sometimes correspond to smaller trade flows that are rounded by the United Nations. To deal with this, we have decided to drop quantities minor than two tons and values less than ten thousands dollars. Note that these two thresholds allow to keep more than $90 \%$ of the trade's value over the period 1995-2004. But this is only one of many plausible explanations of unrealistic evolution of unit values in this kind of detailed database. We have observe however that errors are likely to be correlated between reported values and quantities. Working directly on unit value ratios allow us to eliminate those that seem to be "unrealistic", without trying to understand the source of these errors.

The difficulty relies then on the definition of an "unrealistic" price variation. For instance, one can assert with some confidence that an annual price growth of more than $1,000 \%$ probably reflects a measurement error in the data. However, it may be tricky to fix an ad hoc threshold above which a price variation can be considered as absurd. The magnitude of true price variations can be reasonably large for some sectors. As a consequence, it seems necessary to define a criterion that controls for average price changes at the product level. Based on this constraint, several methodologies have been tested. We finally prefered the one that maximize the value recovery of world trade.

The retained methodology is inspired from Hallak \& Schott (2008). The idea is to keep time changes in unit values that are "consistent" in comparison with the median ratio of the product-specific empirical distribution across countries. Once medians have been computed, observations five times above or below the product-specific median are deleted 18 The exact proceeding is slightly different when considering price ratios used to compute fixed-base and chained price indices. For chained indices, unit values ratios measure price variations between two consecutive years. In our outlier treatment, they are compared with the productspecific median change in unit values computed over the whole period. On the contrary, fixed-base price ratios are compared with the median ratio not only by product but also by

\footnotetext{
${ }^{18}$ The choice of the coefficient for the threshold is ad hoc but not really sensitive. We also tried with a coefficient of 10 and verified that results were qualitatively unchanged.
} 
International Trade Price Indices

Table 1: Recovery rates of our two databases cleaned of outliers (ratio to the total value of imports)

\begin{tabular}{|c|c|c|c|c|c|c|c|c|c|c|}
\hline Country & Database for: & 1996 & 1997 & 1998 & 1999 & 2000 & 2001 & 2002 & 2003 & 2004 \\
\hline USA & $\begin{array}{l}\text { fixed-base indices } \\
\text { chained indices }\end{array}$ & $\begin{array}{l}.90 \\
.90\end{array}$ & $\begin{array}{l}.88 \\
.95\end{array}$ & $\begin{array}{l}.87 \\
.95\end{array}$ & $\begin{array}{l}.84 \\
.92\end{array}$ & $\begin{array}{l}.79 \\
.87\end{array}$ & $\begin{array}{l}.79 \\
.94\end{array}$ & $\begin{array}{l}.77 \\
.92\end{array}$ & $\begin{array}{l}.84 \\
.86\end{array}$ & $\begin{array}{l}.82 \\
.95\end{array}$ \\
\hline France & $\begin{array}{l}\text { fixed-base indices } \\
\text { chained indices }\end{array}$ & $\begin{array}{l}.93 \\
.93\end{array}$ & $\begin{array}{l}.92 \\
.95\end{array}$ & $\begin{array}{l}.91 \\
.95\end{array}$ & $\begin{array}{l}.91 \\
.95\end{array}$ & $\begin{array}{l}.90 \\
.95\end{array}$ & $\begin{array}{l}.90 \\
.95\end{array}$ & $\begin{array}{l}.89 \\
.94\end{array}$ & $\begin{array}{l}.88 \\
.95\end{array}$ & $\begin{array}{l}.88 \\
.96\end{array}$ \\
\hline Germany & $\begin{array}{l}\text { fixed-base indices } \\
\text { chained indices }\end{array}$ & $\begin{array}{l}.97 \\
.97\end{array}$ & $\begin{array}{l}.96 \\
.97\end{array}$ & $\begin{array}{l}.95 \\
.97\end{array}$ & $\begin{array}{l}.95 \\
.97\end{array}$ & $\begin{array}{l}.94 \\
.97\end{array}$ & $\begin{array}{l}.93 \\
.97\end{array}$ & $\begin{array}{l}.93 \\
.97\end{array}$ & $\begin{array}{l}.92 \\
.97\end{array}$ & $\begin{array}{l}.91 \\
.97\end{array}$ \\
\hline China & $\begin{array}{l}\text { fixed-base indices } \\
\text { chained indices }\end{array}$ & $\begin{array}{l}.95 \\
.95\end{array}$ & $\begin{array}{l}.92 \\
.96\end{array}$ & $\begin{array}{l}.91 \\
.96\end{array}$ & $\begin{array}{l}.90 \\
.96\end{array}$ & $\begin{array}{l}.88 \\
.96\end{array}$ & $\begin{array}{l}.86 \\
.97\end{array}$ & $\begin{array}{l}.79 \\
.90\end{array}$ & $\begin{array}{l}.76 \\
.95\end{array}$ & $\begin{array}{l}.74 \\
.96\end{array}$ \\
\hline
\end{tabular}

year. The reason for doing this is that price changes computed with respect to a reference year mechanically increase with the time length between the current and the reference period. This leaves us with two distinct "cleaned of outliers" databases, one with all price ratios used to compute chained indices (the $p_{i j k t} / p_{i j k(t-1)}$ ratios between 0.2 and 5 times the median) and one with ratios used to compute fixed-base indices (the $p_{i j k t} / p_{i j k t_{0}}$ ratios between 0.2 and 5 times the year-specific median). These databases are then used to construct import and export price indices, at the aggregate and the sectoral level ${ }^{19}$

A crucial point in our treatment of outliers concerns the coverage of the "cleaned" databases. It is important that price indices be representative of the whole world trade, as discussed in

\footnotetext{
${ }^{19}$ Thus, the difference with Hallak \& Schott (2008) is that they look at the spatial distribution of unit values (cross-section data) whereas, in our case, we consider the unit values variations over time (panel data).
} 
Silver (2007). In total, we reach recovery rates of 76 and $77 \%$ of the initial world trade in BACI, for fixed-base and chained indices respectively. This total however hide strong disparities across countries. In general, data relative to the largest countries have better coverage than those for small developing countries ${ }^{20}$ This is in part reflecting the better reliability, on average, of developed countries reports. Table 1 shows that the recovery rates of our two databases free of outliers, in terms of the total value of imports, is close to $100 \%$ for main world importers. In contrast, for a few minor or new countries, the recovery rate is very low, once outliers are dropped from the database. Indices for these countries should be used with caution 21

\subsection{Unit Values Aggregation on Different Data Dimensions}

Section 2 has presented different price index formulas in a simplified way: prices were aggregated on the product dimension as if we had only one country. BACI provides however unit values for almost all countries in the world. Price ratios must then to be aggregated at the product level but also at the country level. Namely, country $i$ 's export price index aggregates price ratios in the $(k, j)$ dimension, where $k$ is an HS6 product and $j$ an importing country. For instance, calculated with a Laspeyres formula, the export price index of country $i$ is:

$$
L^{i t}=\sum_{j, k} w_{j k}^{i t_{0}} \frac{p_{i j k t}}{p_{i j k t_{0}}}
$$

while the country $j$ 's Laspeyres import price index is:

$$
L^{j t}=\sum_{i, k} w_{i k}^{j t_{0}} \frac{p_{i j k t}}{p_{i j k t_{0}}}
$$

\footnotetext{
${ }^{20}$ The recovery rate (defined as the total trade value for a given country present in the clean database relative to the value in BACI) exceed $80 \%$ for developed countries.

${ }^{21}$ The unit value indices for the following countries are computed with a recovery rate lower than 1/3: Albania, Antigua and Barbuda, Azerbaijan, Armenia, Bermuda, Bosnia and Herzegovina, British Virgin Islands, Belarus, Cape Verde, Cayman Islands,Democratic Republic of the Congo, Cook Islands, Eritrea, French Polynesia, Djibouti, Georgia, Gambia, Gibraltar, Kiribati, Iraq, Kazakstan, Kyrgyzstan, Nauru, Niger, Norfolk Island, Northern Mariana Islands, Marshall Islands, Papua New Guinea, Pitcairn, Saint Helena, Anguilla, St. Pierre and Miquelon, Sierra Leone. For some other territories, only chained indices have been calculated (countries with missing fixed-base indices are generally those that did not report their trade at the beginning of the period): British Antartic Territory, Christmas Island, Niue, Western Sahara, ship stores and bunkers, and Wallis and Futuna. For Samoa, Coco Island, French Southern Antartic territories, Occupied Palestinian Territory and Guam, it was impossible to compute any index. All other countries are available in our datasets.
} 
International Trade Price Indices

We compute also sectoral indices at the 3-digit level using the ISIC revision 2 classification, by importer and exporter, aggregating the information on 5,000 products in less than $40 \mathrm{sec}-$ tors, $K$. These sectoral indices have then an extra dimension $K$, in addition to the country and year dimensions of previous indices. Namely, the Laspeyres export price index of exporter $i$ in sector ISIC $K$ is:

$$
L^{i K t}=\sum_{j, k \in K} w_{j k}^{i K t_{0}} \frac{p_{i j k t}}{p_{i j k t_{0}}}
$$

Chained and fixed-base indices are computed with the same BACI version covering the 19952004 period. Thus, chained indices start in 1996. We decided to provide fixed-base indices from 1996 as well whereas the chosen reference year is 1995. Aggregate import and export price indices are available on line for 206 countries.

\section{Selected Results}

As a first step, this section provides some illustrations of discrepancies across price index formulas (section 4.1). As a second step, we provide examples of stylized facts that can be inferred from the TradePrices database (section 4.2). We firstly study French and German export prices and ask how they explain differences in these countries' export performances. We then enlarge the analysis to Japan and the United States. Section 4.3 then analyses the terms-of-trade in emerging countries using aggregate and sectoral trade price indices. Finally, section 4.4 uses our indices to deflate world trade in value and compares its evolution with the one in volume.

\subsection{Comparison between Indices}

Section 2 gives insights on the theoretical discrepancies between price indices computed with different formulas. This section tackles the problem empirically to get an idea about the magnitude of these discrepancies. To this aim, we first focus on the correlation between obtained indices.

\subsubsection{Cross-Index Correlation}

Cross-index correlation coefficients for fixed-base and chained import price indices at the country level are displayed in Table $2^{22}$ The Table highlights the strong empirical link between Fisher and Tornqvist indices, which are nearly perfectly correlated. By construction, geometric indices are highly correlated with the Tornqvist index as well, with a correlation coefficient higher than $90 \%$ in the fixed-base case. The correlation with the simple Paasche and

\footnotetext{
${ }^{22}$ Correlations for exports indices are very similar.
} 
Table 2: Correlation between Import Price Indices

\begin{tabular}{|c|c|c|c|c|c|c|}
\hline & $\begin{array}{c}\text { Tornqvist } \\
\mathbf{T}\end{array}$ & $\begin{array}{c}\text { Fisher } \\
\text { F }\end{array}$ & $\begin{array}{c}\text { FIXED-B } \\
\text { Laspeyres } \\
\text { L }\end{array}$ & $\begin{array}{l}\text { ASE INDICES } \\
\text { geo. Laspeyres } \\
\text { gL }\end{array}$ & $\begin{array}{c}\text { Paasche } \\
\text { P }\end{array}$ & $\begin{array}{l}\text { geo. Paasche } \\
\text { gP }\end{array}$ \\
\hline $\begin{array}{l}\text { T } \\
\text { F } \\
\mathbf{L} \\
\text { gL } \\
\mathbf{P} \\
\text { gP }\end{array}$ & 1 & $\begin{array}{c}0.99 \\
1\end{array}$ & $\begin{array}{c}0.83 \\
0.86 \\
1\end{array}$ & $\begin{array}{c}0.9 \\
0.9 \\
0.91 \\
1\end{array}$ & $\begin{array}{c}0.87 \\
0.87 \\
0.51 \\
0.65 \\
1\end{array}$ & $\begin{array}{c}0.91 \\
0.89 \\
0.61 \\
0.65 \\
0.95 \\
1\end{array}$ \\
\hline & cT & $\mathbf{c F}$ & $\begin{array}{l}\text { CHAIN } \\
\text { cL }\end{array}$ & $\begin{array}{c}\text { D INDICES } \\
\text { cgL }\end{array}$ & cP & $\operatorname{cg} P$ \\
\hline $\begin{array}{l}\text { cT } \\
\text { cF } \\
\text { cL } \\
\text { cgL } \\
\text { cP } \\
\text { cgP }\end{array}$ & 1 & $\begin{array}{c}0.99 \\
1\end{array}$ & $\begin{array}{c}0.65 \\
0.67 \\
1\end{array}$ & $\begin{array}{c}0.91 \\
0.9 \\
0.47 \\
1\end{array}$ & $\begin{array}{c}0.6 \\
0.6 \\
-0.18 \\
0.69 \\
1\end{array}$ & $\begin{array}{c}0.91 \\
0.9 \\
0.72 \\
0.66 \\
0.4 \\
1\end{array}$ \\
\hline
\end{tabular}

Note: Pearson correlation coefficients with 2185 (around 200 countries x 10 years) and 2010 (about 200 countries x 9 years) observations in the case of fixed-base and chained indices respectively $($ Prob $>|r|$ under H0: Rho $=0)$. All correlation coefficients significant at the $1 \%$ level

Laspeyres indices is the lowest among all fixed-base indices (only 51\%). As explained later, the low correlation is a consequence of the Gershenkron effect. This confirms our intuition that comparing price indices computed independently by national statistical institutes using either Laspeyres or Paasche formulas may induce a bias. As expected, correlations between chained price indices are lower than in the fixed-base case. This is due to the drift induced by the chaining of elementary indices. In particular, the chained Laspeyres and Paasche, which are especially sensitive to the drift, display a negative correlation coefficient $(-0.18)$. This is why these two indices are not provided on line.

As explained in section 2, chained and fixed-base indices do not measure the same thing. Whereas fixed-base indices measure the price evolution vis-á-vis a reference year, chained indices measure the price evolution year on year. To compare the two types of indices, we focus on the correlation of their yearly variations. Table 3 shows that correlation coefficients 
International Trade Price Indices

Table 3: Correlation Between Yearly Variations of Fixed-base (lines) and Chained (columns) Import Price Indices

\begin{tabular}{l|cccc} 
& c. Tornqvist & c. Fisher & c. geo. Laspeyres & c. geo. Paasche \\
\hline Tornqvist & 0.61 & 0.61 & 0.6 & 0.58 \\
Fisher & 0.6 & 0.59 & 0.59 & 0.56 \\
Laspeyres & 0.45 & 0.45 & 0.45 & 0.42 \\
Paasche & 0.57 & 0.56 & 0.56 & 0.55
\end{tabular}

Note: See note Table 2 Pearson correlation coefficients are calculated here on yearly variations, which corresponds to 1738 observations (around 200 countries x 8 years).

between fixed-base and chained indices vary between 0.45 and 0.61 . This relatively weak correlation reflects information discrepancies between the two types of indices. Fixed-base indices neglect new varieties while chained indices capture extensive margin effects. The comparison shows that this matters when measuring aggregate prices.

\subsubsection{Substitution Bias}

The weak correlation between fixed-base Laspeyres and Paasche indices may reflect the presence of a Gerschenkron effect in our price series (see section 2.1). This Gerschenkron effect reflects the fact that, on average, the weight of a product in the consumption decreases if the product price increases more than the average evolution. In other words, consumers change their consumption towards goods which price increases the less (or decreases the most). To measure this effect, the difference between Laspeyres and Paasche indices is calculated using import price series. In this comparison, we change the reference period each year but do not chain indices. Namely, we compare $L_{t / t-1}$ with $P_{t / t-1}$ over the period 1995-2004. The resulting median gap is positive and quite high (10.5) which supports the Gerschenkron hypothesis: on average, the Laspeyres index tends to be higher than the Paasche index. Moreover, less than $2 \%$ of the observations see their Paasche index exceeding the Laspeyres at some point in time. And countries which do not feature a Gerschenkron effect generally have a low recovery rate 23

\footnotetext{
${ }^{23}$ In our price series, the Gershenkron effect never fails to be verified during more than two years. Moreover, countries having a Paasche index higher than the Laspeyres one are a few African countries (Malawi, Sierra Leone, Liberia), the Chad, Gibraltar and a few little island such as St Hélène, Marshal
} 
Figure 2: Comparison of French fixed-base Price Indices (Reference and Base year: 1995)

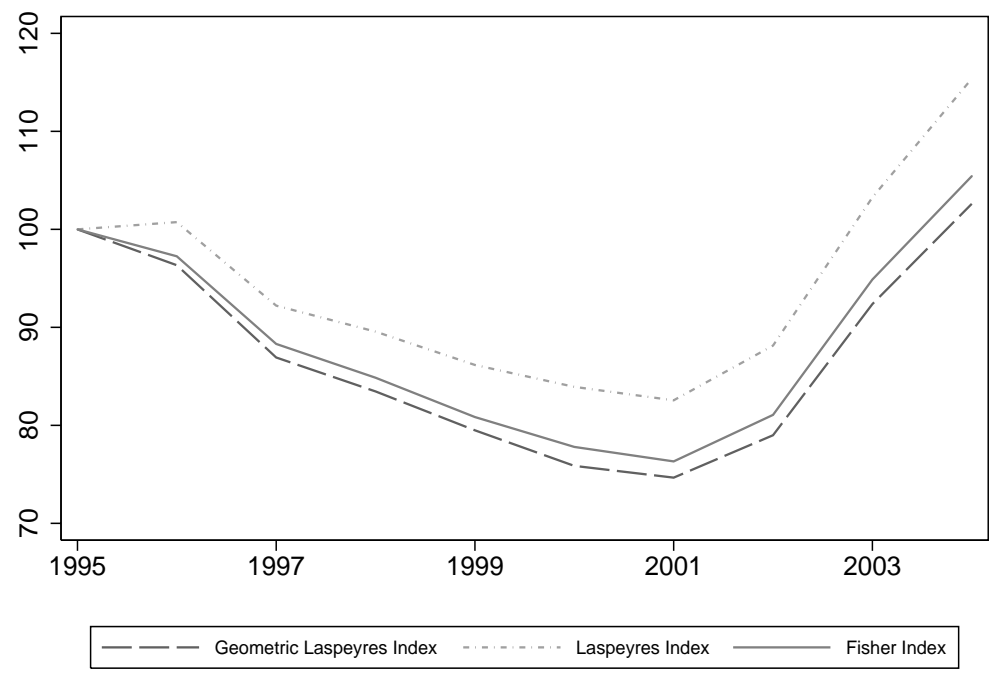

The sensitivity of price indices to substitution effects is further investigated in Figure 2 and Table 4 They compare the Laspeyres, geometric Laspeyres and Fisher fixed-base price indices obtained from French import data. As mentioned above, the Laspeyres index is a timeconstant arithmetic average which does not retain any substitution effect while the geometric Laspeyres implicitly assumes a unitary elasticity of substitution between products, and the Fisher index allows substitution across goods but with a non-unitary elasticity. All these indices are used in their fixed-base form to get rid of the problem of new/disappearing varieties. As expected, the Laspeyres curve is above and the geometric Laspeyres below. Given the fact the Fisher formula is superlative unlike the other two, it can be considered as the "best" measure of import prices. The Laspeyres index overestimates import price growth by neglecting substitution effects. On the contrary, the geometric Laspeyres index underestimates price changes by considering a unitary elasticity of substitution. These discrepancies are not insignificant in quantitative terms. When considering the whole 1996-2004 period, the total gap represents 5.6 percentage points between the Laspeyres and the Fisher price index. The substitution effects are not constant over time, as shown in Table 4 Cross-index dif-

Island, Norfolk Island. 
International Trade Price Indices

Table 4: Substitution bias in French import prices : yearly variations of different price indices (in \%)

\begin{tabular}{c|ccc}
\hline \hline Year & Laspeyres & Fisher & $\begin{array}{c}\text { Geometric } \\
\text { Laspeyres }\end{array}$ \\
\hline & & & \\
1996 & 0.7 & -3.7 & -2.7 \\
1997 & -8.5 & -9.2 & -9.8 \\
1998 & -2.9 & -3.9 & -4 \\
1999 & -3.8 & -4.7 & -4.8 \\
2000 & -2.6 & -3.8 & -4.6 \\
2001 & -1.6 & -1.9 & -1.6 \\
2002 & 6.8 & 6.2 & 5.8 \\
2003 & 17.2 & 17 & 17 \\
2004 & 11.8 & 11.1 & 11.1 \\
& & & \\
\hline \hline
\end{tabular}

ferences in the measured annual growth rate of French import prices are shown to reach a maximum in 2000 (difference between -4.6 and -2.6). The substitution effect seems to be higher when prices decrease than when they increase. A possible explanation is that the French import price increase since 2001 is mainly due to the oil price rise, that can hardly be dampened by substitution towards other goods.

To sum up, all these indices (except chained Paasche and chained Laspeyres) are positively correlated with a quite strong correlation. However, there are differences in price evolutions due to the use of different aggregation formulas. The choice of the price index is then non neutral, especially for international comparisons.

\subsection{Export Prices in Developed Countries}

Our unit value indices permit various comparisons. In particular it is possible to compare price evolutions across exporting countries to get insights on their relative competitiveness in international markets. 
Figure 3: French and German Export Price Indices in Euro Markets (chained Tornqvist, Base year 2000)

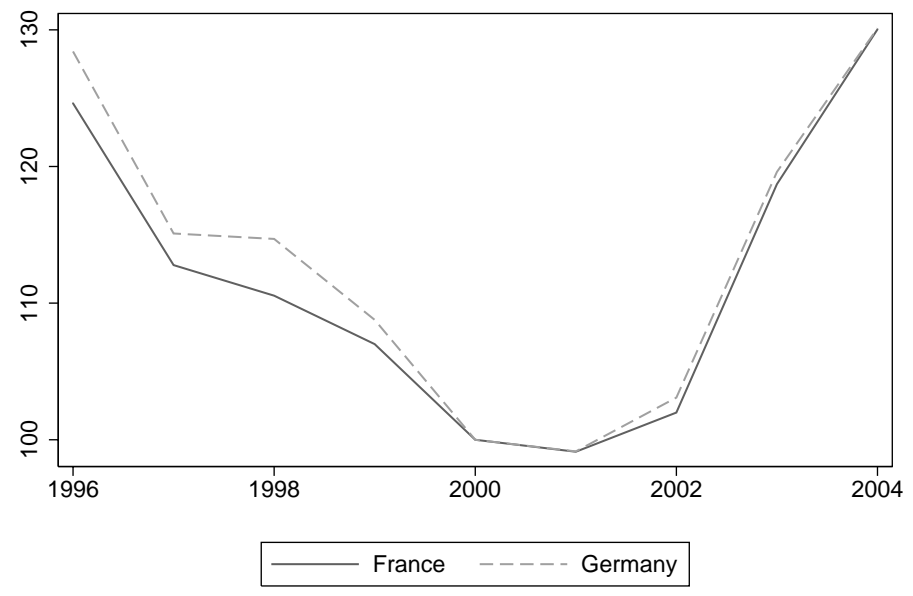

\subsubsection{German and French Export Prices at the Aggregate Level}

The relative performance of French and German exporters is a topic of discussions in French political and economic circles ${ }^{24}$ The debate lies on explaining the deterioration of the French trade balance, that contrasts with the German export dynamism. A central point in this debate is to determine whether this reflects a competitiveness loss for French firms engaged in international markets or unfavorable specialization patterns for France. Figures 3 and 4 provide some elements of answer through an illustration of the dynamics of these countries' export price indices towards the euro zone. We restrict our attention to the euro area markets for three main reasons. Firstly, because Germany and France export a similar basket of goods to Europe which limits the impact of differences in their geographic specialization pattern. Secondly, focusing on the euro area allows us to control for exchange rate effects. As the source datasets are denominated in US dollars (whatever the transaction currency) considering all exports makes it difficult to distinguish between price evolutions and exchange rate effects. As intra euro zone exports are mostly denominated in euro, one can convert price indices and

\footnotetext{
${ }^{24}$ See for instance the report of the French Council of Economic Analysis (CAE), Artus \& Fontagné (2006).
} 
isolate "pure" price variations. Lastly, studying export prices towards euro countries (with and without correction for dollar fluctuations) gives insights about pricing strategies. To sum up, we present two figures: Figure 3 provides French and German export prices towards euro area computed from BACI data i.e. in USD whereas in Figure 4 price changes are corrected from exchange rate variation between euro and US dollar in order to eliminate the exchange rate effect.

Figure 4: French and German Export Price Indices in Euro Markets, Corrected for Dollar Fluctuations (chained Tornqvist, Base year 2000)

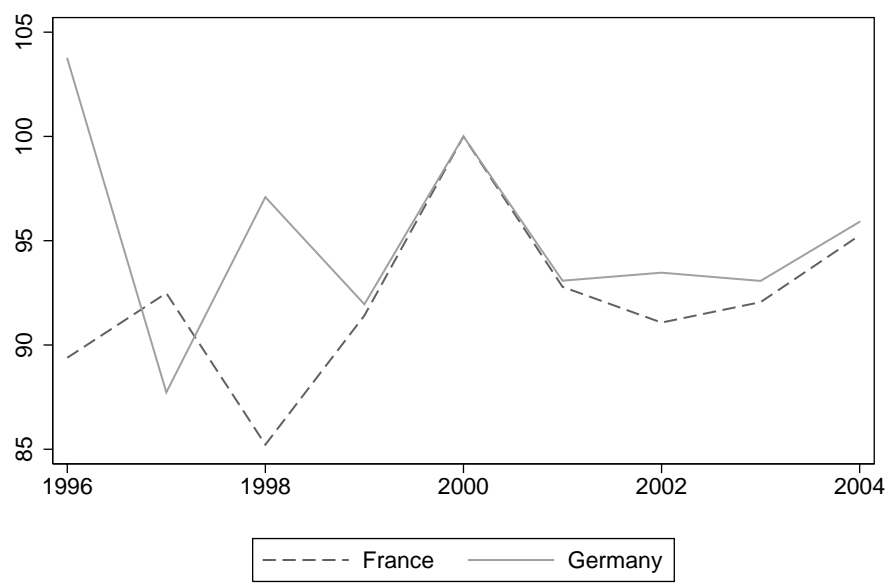

Price variations pictured in Figure 3 are in US dollars and thus mainly reflect variations in the EUR/USD exchange rate. In particular, the rise in export prices from 2001 is due to the appreciation of the euro vis-à-vis the dollar. However, as both France and Germany face the same exchange rate risk, this figure cannot explain the relative performances of these countries. To capture this relative performances, Figure 4 corrects price evolutions from exchange rate variations. As expected, the correction for exchange-rate variations strongly reduces the scale of measured price movements observed in Figure 3 (see details in Table 5). A visual inspection shows that price evolutions are closer after 1999, since the introduction of the euro. In contrast to the common view, French exporters gained in competitiveness in 2001 and 2002 with respect to their German competitors. In a nutshell, the price discrepancies between the two countries are not huge and can hardly explain the gap in French and German trade performances. 
Table 5: Annual Growth of French and German Export Prices in European markets

\begin{tabular}{c|ccc|ccc}
\hline \hline & $\begin{array}{c}\text { Chained } \\
\text { Tornqvist } \\
\text { in dollar }\end{array}$ & $\begin{array}{c}\text { Exchange } \\
\text { Rate }(a) \\
\text { euro/dollar }\end{array}$ & $\begin{array}{c}\text { Chained } \\
\text { Tornqvist } \\
\text { in euro }\end{array}$ & $\begin{array}{c}\text { Chained } \\
\text { Tornqvist } \\
\text { in dollar }\end{array}$ & $\begin{array}{c}\text { GERMANY } \\
\text { Exchange } \\
\text { Rate }^{(a)} \\
\text { euro/dollar }\end{array}$ & $\begin{array}{c}\text { Chained } \\
\text { Tornqvist } \\
\text { in euro }\end{array}$ \\
\hline & & & & & & \\
1997 & $-10.3 \%$ & $-13.3 \%$ & $3.5 \%$ & $-11.4 \%$ & $4.8 \%$ & $-15.4 \%$ \\
1998 & $-3.2 \%$ & $5.0 \%$ & $-7.9 \%$ & $-0.8 \%$ & $-10.3 \%$ & $10.7 \%$ \\
2000 & $-3.8 \%$ & $-10.3 \%$ & $7.3 \%$ & $-5.3 \%$ & $0.0 \%$ & $-5.3 \%$ \\
2001 & $-8.5 \%$ & $-16.4 \%$ & $9.4 \%$ & $-9.0 \%$ & $-16.4 \%$ & $8.8 \%$ \\
2002 & $-2.0 \%$ & $5.6 \%$ & $-7.2 \%$ & $-1.7 \%$ & $5.6 \%$ & $-6.9 \%$ \\
2003 & $18.9 \%$ & $5.8 \%$ & $-1.8 \%$ & $6.2 \%$ & $5.8 \%$ & $0.4 \%$ \\
2004 & $10.7 \%$ & $17.4 \%$ & $1.1 \%$ & $17.0 \%$ & $17.4 \%$ & $-0.4 \%$ \\
\hline \hline
\end{tabular}

Note that French and German export prices increase in euro after 2001, despite the depreciation of the dollar. Even if France and Germany probably export in euro in the euro area, some of their competitors such as the US or China do export in dollars, which makes their products cheaper. A possible explanation is that, confronted to Chinese and US competition, French and German exporters did not lower their prices, but improved the quality of their exports ${ }^{25}$

\subsubsection{Export Price Indices for Germany, the USA and Japan}

We compare now the Laspeyres and chained Tornqvist of German, US and Japanese export prices (in US dollars) in order to separate price evolutions and changes in the structure of trade (Figure 5). At first sight, the chained Tornqvist (on the left hand side of the figure) and fixed-base Laspeyres indices (on the right hand side) look very similar. This is because exchange rate variations of the euro (deutschmark until 1999) and yen are the main drivers of German and Japanese dollar denominated export unit values. The comparison of both

\footnotetext{
${ }^{25}$ Empirical evidence of this response to higher competition can be found for instance in Fontagné \& Paillacar (2007). They show that, during the 1995-2004 period, German products exported to the US gained market shares whereas their prices increase. Their interpretation is that Chinese competition lead Germany to export higher quality products.
} 
Figure 5: German, US and Japanese Laspeyres and chained Tornqvist Export Prices (Base year 2000)

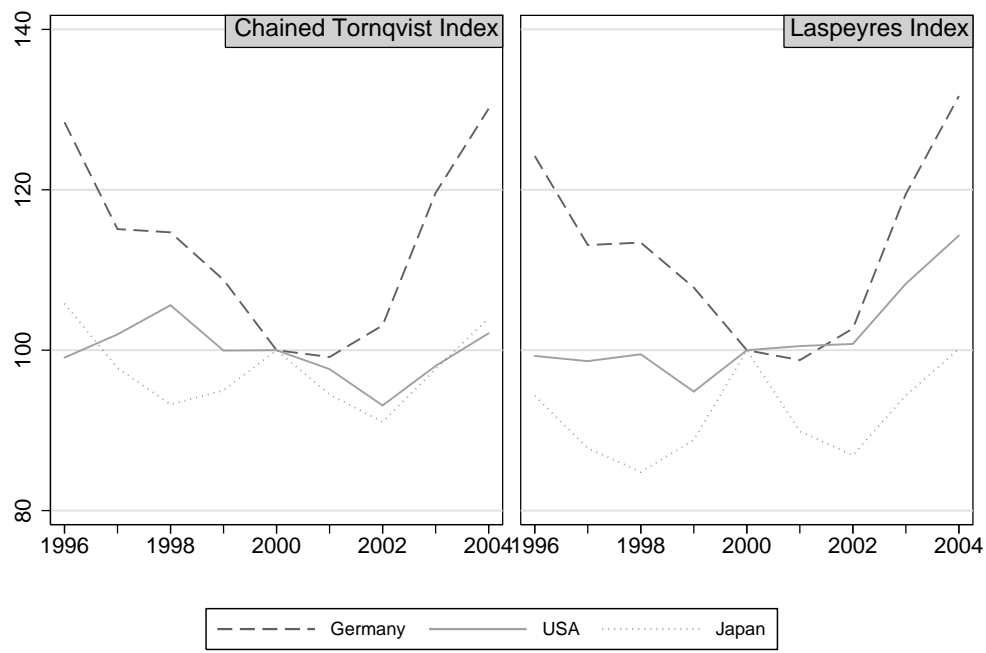

indices is easier for the US: the faster growth of the Laspeyres index reflects the growing share in the US export basket of sophisticated goods with downward prices. The chained Tornqvist takes into account this composition effect as well as the entry of new products while the Laspeyres index neglects both. Laspeyres and Tornqvist indices profiles are much more similar for Germany, reflecting a more stable specialization. Compared to Laspeyres, the Tornqvist index for Japan dampens changes due to nominal exchange rate fluctuations, possibly revealing a smooth adaptation of the Japanese specialization.

Figure 6 presents the price evolution of the three chained Tornqvist series, corrected for changes in nominal exchange rates. The German price index is more stable, once converted into euro, whereas Japenese prices in yen are more volatile. There is a peak of inflation in 1998, that corresponds to the beginning of the Asian crisis. However, this peak is not visible in Figure 5 which means that the depreciation of the yen prevented an increase in Japanese export prices in dollars. 
Figure 6: German, US and Japanese chained Tornqvist Export Prices, Corrected for Dollar Fluctuations (Base year 2000)

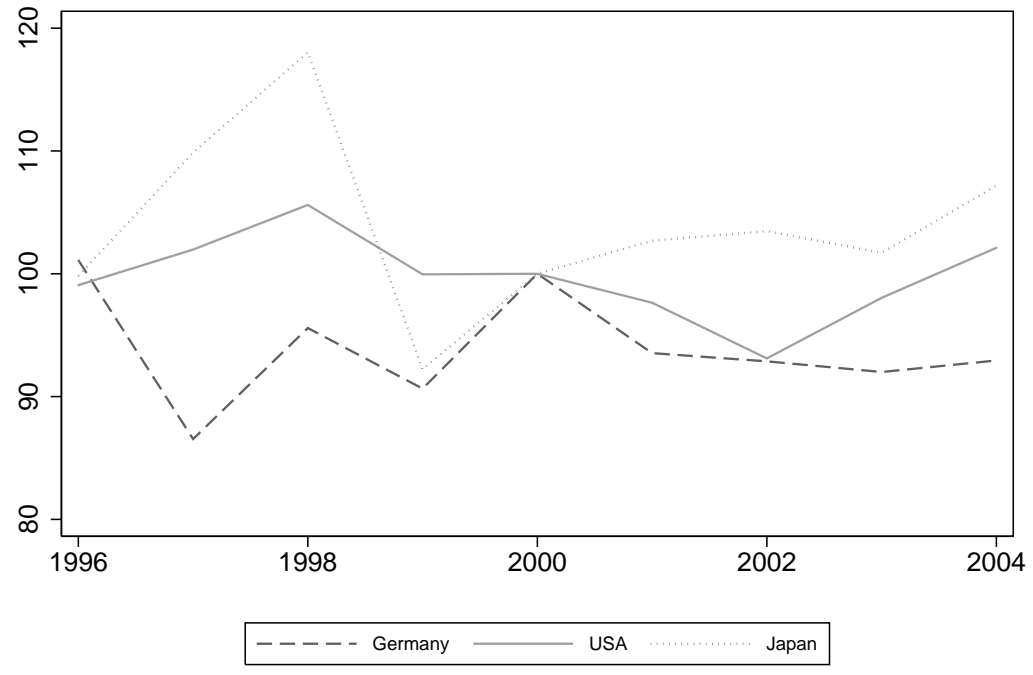

\subsection{Terms-of-Trade in Emerging Countries}

Export and import price indices can also be used to compute a country's terms-of-trade (ToT), a critical variable in many open macroeconomic models. Terms-of-trade are an important determinant of aggregate trade and their measure helps explaining global imbalances at the world level. Figure 7 illustrates the terms-of-trade, defined as the ratio of export to import prices, the largest emerging countries: Brazil, Russia, India and China (BRIC hereafter). With this definition, an increase in the price ratio reflects an improvement in the country's terms-of-trade.

Figure 7 highlights some discrepancies across countries. Over the 2002-2004 period, Russia and Brazil benefit from a terms-of-trade improvement whereas India and China observe a decrease in the relative price of their exports. The boom of resource-based good prices (agriculture, mining and quarrying) probably explains part of this difference for Russia, which is a big primary goods' exporter. This contrasts with China and India which are net importers of primary goods and they export manufactured products, which prices tend to decline. The sectoral decomposition of these countries' trade helps understanding the mechanisms at work. 
International Trade Price Indices

Table 6: BRICs Sectoral Export (X) and Import (M) Prices Variations (chained Tornqvist, \%) and Average Sectoral Weigth in the Total Trade over the Period

\begin{tabular}{|c|c|c|c|c|c|c|c|c|}
\hline & \multicolumn{2}{|c|}{ Agriculture } & \multicolumn{2}{|c|}{ Mining \& Quarrying } & \multicolumn{2}{|c|}{ Manufacturing } & \multicolumn{2}{|c|}{$\overline{\text { Total }}$} \\
\hline & $\mathrm{X}$ & $\mathrm{M}$ & $\mathrm{X}$ & $\mathrm{M}$ & $X$ & $\mathrm{M}$ & $\mathrm{X}$ & M \\
\hline & \multicolumn{8}{|c|}{ B R A Z I L } \\
\hline 1997 & 11.67 & -9.7 & -2.4 & -6.2 & -2.7 & -2.7 & -1.3 & -3.3 \\
\hline 1998 & -16.2 & -12.5 & 4.4 & -23.6 & -3.9 & -2.0 & -4.8 & -3.8 \\
\hline 1999 & -21.3 & -9.3 & -11.2 & 7.8 & -9.9 & -0.1 & -11.3 & -0.1 \\
\hline 2000 & -1.9 & -8.9 & 0.6 & 48.2 & 0.8 & -1.1 & 0.6 & 1.0 \\
\hline 2001 & -17.6 & 2.1 & -1.1 & -14.9 & -1.6 & -1.8 & -3.3 & -2.6 \\
\hline 2002 & -4.3 & -4.5 & 0.8 & 1.9 & -5.4 & -2.4 & -4.8 & -2.2 \\
\hline 2003 & 15.3 & 24.1 & 10.8 & 17.5 & 5.4 & -1.1 & 6.9 & 1.1 \\
\hline 2004 & 26.1 & 11.8 & 17.8 & 11.6 & 10.7 & 7.9 & 13.2 & 8.4 \\
\hline \multirow[t]{2}{*}{ Average shares } & 0.09 & 0.04 & 0.08 & 0.09 & 0.82 & 0.87 & & \\
\hline & \multicolumn{8}{|c|}{ R U S S I A } \\
\hline 1997 & -6.6 & -10.7 & 7.5 & 5.8 & -3.8 & -7.2 & 1.1 & -7.0 \\
\hline 1998 & -10.5 & -3.8 & -27.4 & -7.6 & -12.1 & 3.1 & -19.3 & 2.4 \\
\hline 1999 & -5.7 & -12.4 & -5.3 & -20.6 & -9.0 & -8.9 & -7.6 & -9.4 \\
\hline 2000 & -3.8 & -6.5 & 77.0 & 54.3 & 22.2 & -8.7 & 44.1 & -7.1 \\
\hline 2001 & -2.0 & -3.6 & -7.5 & -0.8 & -4.8 & 0.8 & -6.1 & 0.6 \\
\hline 2002 & 0.3 & 3.8 & -2.5 & -10.1 & -0.9 & 0.2 & -1.6 & 0.0 \\
\hline 2003 & 11.4 & 7.9 & 15.8 & 11.4 & 14.6 & 8.9 & 15.3 & 9.0 \\
\hline 2004 & 15.1 & 9.9 & 27.3 & 26.6 & 26.0 & 7.8 & 26.6 & 8.2 \\
\hline \multirow[t]{2}{*}{ Average shares } & 0.02 & 0.05 & 0.41 & 0.03 & 0.54 & 0.92 & & \\
\hline & \multicolumn{8}{|c|}{ I N D I A } \\
\hline 1997 & 0.1 & -5.5 & -5.1 & -19.2 & -1.0 & -8.1 & -1.1 & -10.0 \\
\hline 1998 & -1.0 & -8.6 & 0.2 & -27.6 & -4.6 & -7.5 & -4.1 & -10.8 \\
\hline 1999 & -1.5 & -0.8 & -6.6 & 60.5 & -5.5 & -5.1 & -5.3 & 6.7 \\
\hline 2000 & -6.8 & -5.3 & 4.7 & 8.6 & -1.3 & -2.9 & -1.4 & -2.0 \\
\hline 2001 & -12.8 & -8.2 & -3.5 & -13.7 & -5.0 & -2.3 & -5.5 & -6.5 \\
\hline 2002 & -8.7 & -2.0 & -9.1 & 12.2 & -2.6 & -2.1 & -3.2 & 2.5 \\
\hline 2003 & 13.1 & 5.9 & 23.9 & 22.4 & 7.0 & 13.0 & 8.0 & 13.9 \\
\hline 2004 & 4.4 & 6.8 & -1.0 & 33.1 & 8.9 & 11.7 & 8.6 & 14.0 \\
\hline \multirow[t]{2}{*}{ Average shares } & 0.06 & 0.03 & 0.03 & 0.29 & 0.90 & 0.67 & & \\
\hline & \multicolumn{8}{|c|}{ C H I N A } \\
\hline 1997 & -4.5 & -6.4 & -5.0 & -12.3 & -2.3 & -4.4 & -2.5 & -4.7 \\
\hline 1998 & -6.8 & -13.8 & -14.4 & -25.4 & -4.4 & -6.9 & -4.7 & -7.8 \\
\hline 1999 & -6.3 & -11.4 & -3.8 & 22.2 & -5.4 & -1.7 & -5.4 & -1.7 \\
\hline 2000 & -3.0 & -1.1 & 17.2 & 36.4 & -0.6 & 8.6 & -0.4 & 9.3 \\
\hline 2001 & -2.8 & -5.1 & 3.8 & -8.8 & -2.4 & -5.4 & -2.3 & -5.6 \\
\hline 2002 & -2.8 & 9.7 & -4.4 & -2.8 & -3.2 & 0.3 & -3.2 & 0.5 \\
\hline 2003 & 5.8 & 12.5 & 6.6 & 14.7 & 6.7 & 11.8 & 6.6 & 12.1 \\
\hline 2004 & 10.8 & 9.3 & 41.0 & 24.5 & 6.5 & 10.1 & 7.0 & 10.6 \\
\hline Average shares & 0.02 & 0.04 & 0.02 & 0.06 & 0.95 & 0.89 & & \\
\hline
\end{tabular}


Figure 7: Terms-of-Trade of Biggest Emerging Markets

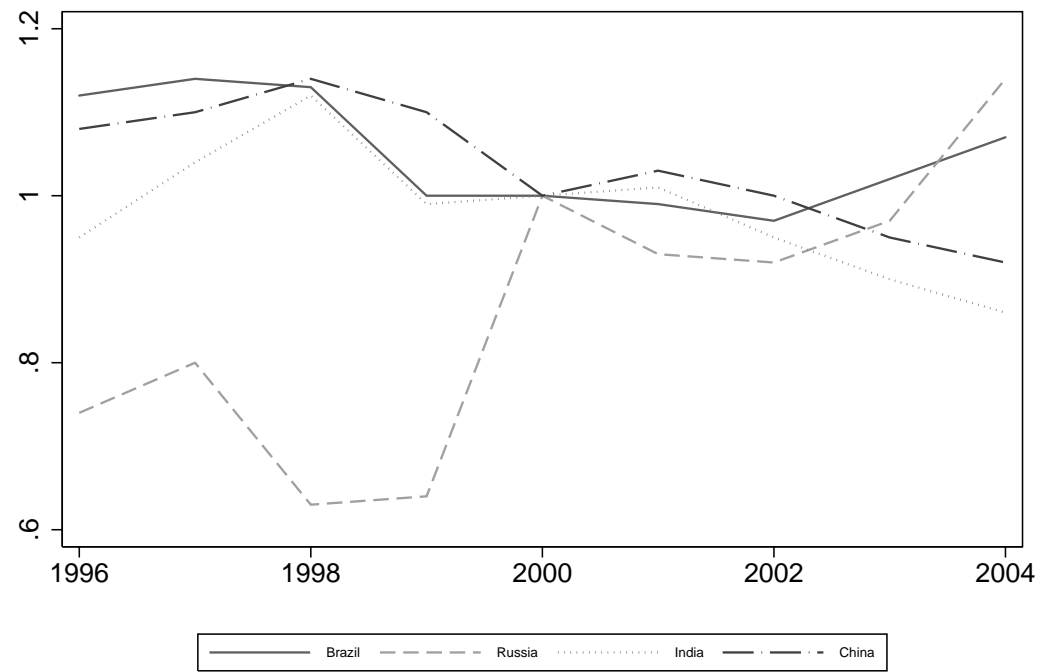

Note: TOT are defined as the ratio of chained Tornqvist export indices over chained Tornqvist import indices.

To do this, Table 6 focuses on the evolution of trade prices by sector for the BRICs countries decomposed in three large sectors: "Agriculture", "Mining and quarrying", and "Manufacturing". The average share of each sector in the considered country's total trade over the period 1996-2004 is also added to get an idea of these countries' trade structure. Brazilian and Chinese trade structures are mainly oriented towards manufactured goods on both the export and the import sides. On the contrary, Russian exports are much more oriented towards the mining and quarrying sector, that represents more than $40 \%$ of the total exported value. This contrast a lot with India, which is in the opposite situation of a higher dependency with respect to mining and quarrying imports ${ }^{26}$

Our results show that the deterioration of Chinese terms of trade is due to changes in their import and export manufacturing prices. The really weak share of primary goods in Chinese trade cannot explain the TOT evolution. During the 2001-2004 period, import prices of manufacturing goods rise more than export prices, which explains the deterioration of Chinese

\footnotetext{
${ }^{26}$ In other words, the primary activity represents respectively 17 and 43 percent of Brazilian and Russian exports versus only 9 and 4 percent of Indian and Chinese exports. Moreover, India and China import 32 and 10 percent of primary goods.
} 
TOT over this period. The Indian TOT deterioration has several roots. Firstly, the inflation of primary goods. Although, the agricultural sector only represents a small share of Indian trade, the mining and quarrying sector represents $29 \%$ of Indian imports. Thus, the increase in gas and oil prices badly affects Indian terms of trade. Secondly, as for China, prices of manufacturing Indian imports rose more than their export prices in the beginning of the 2000's. It might be a consequence of their fast development leading this two countries to import higher quality goods. On the contrary, the Brazilian and Russian manufactured export prices rose more than the prices of their manufactured imports, which reinforces the improvement in their TOT in the primary sector (in 2004 for Brazil and since 2003 for Russia). Note that the impressive Russian ToT improvement observed in 2000 is closely related to the boom of mining and quarrying prices (and specifically the boom of gas price).

\subsection{International Trade Values and Volumes}

Price indices can also been used as deflators to convert trade values in volumes. This allows us to isolate variations in traded quantities from price effects. In this section, we deflate values with the chained Tornqvist index, which base year is 2000 . Figure 8 presents world trade in

Figure 8: World Trade Values and Volumes (deflated with chained Tornqvist indices, in thousand billion US\$)

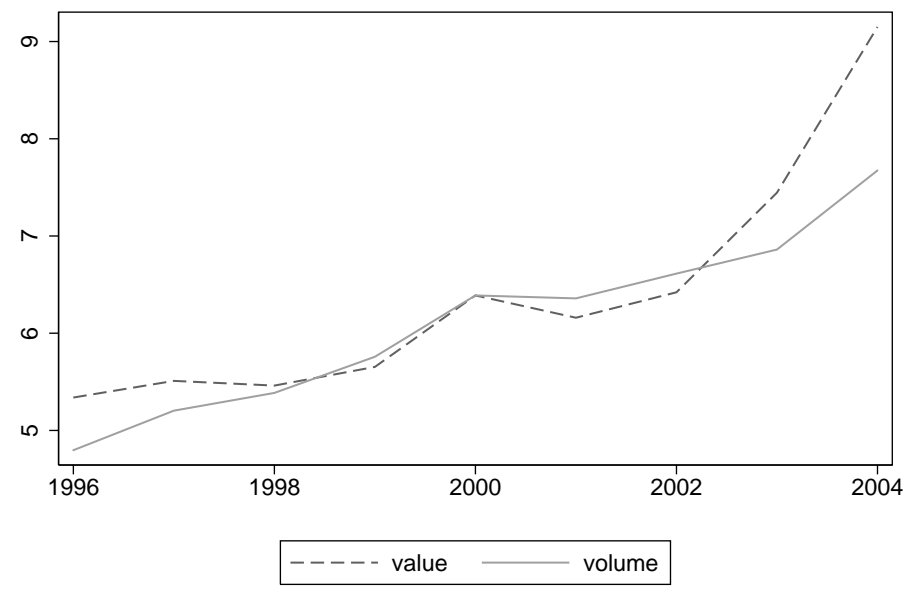

value and volume and Table 7 their associated growth rates. The most impressive result is 
CEPII, Working Paper. No 2008-10

that the boom in world trade value observed at the world level since 2002 is not associated with such a boom in terms of volumes. This means that the boom is essentially due to a jump in trade prices.

Table 7: World Traded Values and Volumes, Yearly Variations in Percent (deflated with chained Tornqvist indices)

\begin{tabular}{|c|c|c|c|c|c|c|c|c|}
\hline year & 1997 & 1998 & 1999 & 2000 & 2001 & 2002 & 2003 & 2004 \\
\hline volume & 8.5 & 3.5 & 6.9 & 11.0 & -0.5 & 4.0 & 3.7 & 11.9 \\
\hline \multirow[t]{3}{*}{ value } & 3.2 & -0.9 & 3.5 & 13.0 & -3.6 & 4.2 & 16.0 & 22.9 \\
\hline & \multirow{2}{*}{\multicolumn{2}{|c|}{$\begin{array}{c}\text { average } \\
\text { growth rate* }\end{array}$}} & \multicolumn{6}{|c|}{ annualized variations } \\
\hline & & & \multicolumn{3}{|c|}{ 1997-2004 } & \multicolumn{3}{|c|}{$2002-2004$} \\
\hline \multirow{2}{*}{$\begin{array}{l}\text { volume } \\
\text { value }\end{array}$} & \multicolumn{2}{|c|}{6.1} & \multirow{2}{*}{\multicolumn{3}{|c|}{5.4}} & \multicolumn{3}{|c|}{7.7} \\
\hline & \multicolumn{2}{|c|}{7.3} & \multicolumn{2}{|r|}{6.9} & & \multicolumn{3}{|c|}{19.4} \\
\hline
\end{tabular}

* arithmetic average of yearly growth rates

We compute trade price indices according to their stage of production using a simplified version of the United Nations' Broad Economic Classification (BEC) in order to distinguish primary, consumption, investment and intermediate goods ${ }^{27}$ Table 8 presents the value and volume evolutions of these four types of traded goods. There is a fall in 2001 in the value and volume of investment, intermediate and primary goods. This fall is arguably due to the slowdown of the global activity (due to the 9/11 attacks and the burst of the ITC bubble). Consumption goods is the only kind of goods which both value and volume rise each year over the period.

For the last two years of our sample, we face a huge increase in both traded values and volumes for the four sectors. These figures are quite interesting to underline the volume data usefulness. Focusing on value variations, it appears that the primary sector is the most dynamic one in 2003 and 2004. But in reality, the boom of primary good values is essentially due to price increases. And considering the volumes, the most dynamic sector in 2003 and 2004 (i.e. the sector which experiences the highest real growth of trade) is the investment good sector.

\footnotetext{
${ }^{27}$ Our SAS programs, available on line, allow us to easily change the sectoral key of aggregation.
} 
Table 8: World Traded Values and Volumes by Stage of Production, Yearly Variations in Percent (deflated with chained Tornqvist indices, in thousand billion US\$)

\begin{tabular}{c|cc|cc|cc|cc}
\hline \hline & \multicolumn{2}{|c|}{ Intermediate goods } & \multicolumn{2}{|c|}{ Primary goods } & \multicolumn{2}{c|}{ Investment goods } & \multicolumn{2}{c}{ Consumption goods } \\
\hline & volume & value & volume & value & volume & value & volume & value \\
\hline 1997 & 9.2 & 3.0 & 4.1 & -0.2 & 9.7 & 6.1 & 8.1 & 2.9 \\
1998 & 3.2 & 0.1 & 0.6 & -20.4 & 5.6 & 2.7 & 3.9 & 2.8 \\
1999 & 7.0 & 2.5 & 5.8 & 12.4 & 6.9 & 3.0 & 6.9 & 3.0 \\
2000 & 11.7 & 13.5 & 7.6 & 45.0 & 12.2 & 9.1 & 8.9 & 3.7 \\
2001 & -1.7 & -5.6 & 1.4 & -7.5 & -2.4 & -3.7 & 2.9 & 2.5 \\
2002 & 5.1 & 3.7 & -0.8 & 0.1 & 2.6 & 3.3 & 5.2 & 7.8 \\
2003 & 3.8 & 16.3 & 3.4 & 20.5 & 4.1 & 13.6 & 3.5 & 15.3 \\
2004 & 11.7 & 23.5 & 13.1 & 38.4 & 16.5 & 21.8 & 7.9 & 15.8 \\
\hline \hline
\end{tabular}

\section{Concluding Remarks}

This paper describes TradePrices, the new CEPII database providing international trade price indices allowing international comparisons at both the aggregate and the sectoral level, and available on line.

In a first step, we present the different index formulas relating them to the economic theory. We show that the different indices rely on different assumptions about the elasticity of substitution. Namely, Laspeyres and Paasche indices assume that goods are complements (no substitution) whereas Fisher and Tornqvist indices imply different elasticities of substitution. We also stress the impact of chaining on the weighting scheme of the indices.

The trade price indices are computed using BACI's unit values. The database is described in a second step, in which we recall that proxying prices by unit values presents some drawbacks, even if they are limited by our treatment of outliers and the high level of disaggregation of our data. We are aware of this issue but observed prices are not available on a world-wide basis. Waiting for international data (with a large coverage) on observed prices of traded products, trade unit values turn out to be quite relevant.

Empirical evidence presented in the last section confirms that the aggregation method matters. Actually, the correlation between indices is far from perfect, especially between Laspeyres and Paasche indices. Comparing different indices computed for the US, China and Germany, we also show the importance of taking into account the new products (i.e. the extensive margin). 
Finally, we highlight some applications of our indices. Comparing French and German export performances we show that prices increased despite of the unfavorable evolution of dollar against euro, which might reflect changes in quality of French and German exports. Then, we focus on the recent evolution of emerging countries terms of trade showing their main sectoral determinants. To end, we compare the evolution of world trade in value and volume in order to distinguish between evolution of prices and quantities and show, for instance, that the boom in the value of primary goods trade is essentially due to price increase.

\section{References}

Allen, R. C. \& Diewert, W. E. (1981), 'Direct versus implicit superlative index number formulae', The Review of Economics and Statistics 63(3), 430-35.

Alterman, W. (1991), Price trends in u.s. trade: New data, new insights, in P. Hooper \& J. D. Richardson, eds, 'International economic transactions: Issues in measurement and empirical research', Vol. Vol. 55 of NBER Studies in Income and Wealth, Chicago: University of Chicago Press, pp. pp. 109-39.

Artus, P. \& Fontagné, L. (2006), Evolution récente du commerce extérieur français, Vol. 64, Rapport du CAE.

Berthier (2003), 'Le chainage des indices', Courrier des Statistiques (108), 15-26.

Broda, C. \& Weinstein, D. (2006), 'Globalization and the gains from variety', The Quaterly Journal of Economics 121 issue 2, 541-585.

Diewert, W. E. (1976), 'Exact and superlative index numbers', Journal of Econometrics 4(2), 115-145. (available at http://ideas.repec.org/a/eee/econom/v4y1976i2p115145.html).

Feenstra, R. C. (1994), 'New Product Varieties and the Measurement of International Prices', American Economic Review (1), 84, 157-77.

Feenstra, R. C. (1997), U.s. exports, 1972-1994: With state exports and other u.s. data, NBER Working Papers 5990.

Feenstra, R. C. (2004), Advanced International Trade: Theory and Evidence, Princeton University Press.

Feenstra, R. C. \& Shapiro, M. D. (2001), 'High-Frequency Substitution and the Measurement of Price Indexes', NBER Working Papers.

Fisher, I. (1922), The Making of Index Numbers, Houghton Mifflin, Boston. 
Fontagné, L. \& Paillacar, R. (2007), 'China is shipping more products to the united states than germany', La Lettre $d u$ CEPII. (http://www.cepii.fr/anglaisgraph/publications/lettre/pdf/2007/let270ang.pdf).

Gaulier, G. \& Mejean, I. (2006), Import prices, variety and the extensive margin of trade, CEPII Working Papers 2006-17.

Gaulier, G., Paillacar, R. \& Zignago, S. (2008), Baci: A world database of international trade at the product level, 1995-2004 version, CEPII Working Paper forthcoming.

Hallak, J. \& Schott, P. (2008), Estimating Cross Country Differences in Product Quality, NBER Working Paper 13807.

Kravis, I. \& Lipsey, R. (1974), International Trade Prices and Price Proxies, in N. Ruggles, ed., 'The Role of the Computer in Economic and Social Research in Latin America', New York : Columbia University Press, pp. 253-66.

Silver, M. (2007), 'Do unit value Export, Import, and Terms of Trade Indices Represent or Misrepresent Price Indices?', IMF Working Paper p. 07/121.

UNSD (2005), National practices in compilation and dissemination of external trade index numbers, Statistical Papers Series F No.86, Department of Economic and Social Affairs, Statistics Division, United Nations, ST/ESA/STAT/SER.F/86.

\section{A Appendices}

\section{A.1 Desirable mathematical properties of price indices}

Fisher (1922) defines various mathematical properties to evaluate price indices. Here are the most important.

- Identity: if prices are the same in the two periods and if the weight of each product is constant, the index has to equal one.

- Proportionality: if each price is multiplied by a constant, the index has to be multiplied in the same proportion.

- Commensurability: the price index has to be invariant in changes of units.

- Time Reversal: an index between period A and B has to equal the inverse index between B and A.

- Monotonicity: if no price decreases and at least one raises, the index has to rise.

- Circularity: the index between periods 1 and 3 has to equal the index between 1 and 2 time the index between 2 and 3 . 
- Factor Reversal: a price index multiplied by its corresponding quantity index is equal to the ratio of the values for the two periods considered.

A perfect index should verify each of those properties. Yet, Eicchorn and Voeller proves in 1976 that no index can satisfy all properties. The Table A.1 evaluates our price indices in terms of these properties.

Table A.1 : Fisher Axioms and Price Indices

\begin{tabular}{l|ccccccc}
\hline \hline Index & Identity & $\begin{array}{c}\text { Commen- } \\
\text { surability }\end{array}$ & $\begin{array}{c}\text { Propor- } \\
\text { tionality }\end{array}$ & $\begin{array}{c}\text { Time } \\
\text { Reversal }\end{array}$ & $\begin{array}{c}\text { Monoto- } \\
\text { nicity }\end{array}$ & $\begin{array}{c}\text { Circu- } \\
\text { larity }\end{array}$ & $\begin{array}{c}\text { Factor } \\
\text { Reversal }\end{array}$ \\
\hline Laspeyres & yes & yes & yes & & yes & & \\
geo. Lasp. & yes & yes & yes & & yes & & \\
Paasche & yes & yes & yes & & & & \\
geo. Paas. & yes & yes & yes & & & & yes \\
Fisher & yes & yes & yes & yes & yes & & yes \\
Tornqvist & yes & yes & yes & yes & & & \\
\hline \hline
\end{tabular}

Chained indices do not pass the circularity test. The Fisher index is the best index considering these criteria. This approach to evaluate price indices is not however the one favored in this paper. It indeed assumes an independence between prices and quantities. Moreover, it is a mathematical approach which is difficult to reconcile with underlying economic concepts. 


\section{A.2 Complementary results}

Table A.2 : Annual Growth in Observed Prices and BACI's Unit Value index for Crude

\begin{tabular}{l|cc}
\hline \hline Year & Crude Price & HS2709 \\
\hline 1997 & $-7 \%$ & $-6 \%$ \\
1998 & $-30 \%$ & $-33 \%$ \\
1999 & $33 \%$ & $34 \%$ \\
2000 & $58 \%$ & $66 \%$ \\
2001 & $-15 \%$ & $-15 \%$ \\
2002 & $1 \%$ & $2 \%$ \\
2003 & $19 \%$ & $18 \%$ \\
2004 & $33 \%$ & $26 \%$ \\
\hline \hline
\end{tabular}

Source: IFS for observed prices and BACI for unit value indices.

Note: The unit value index is computed using data on the hs2709 sector ("Crude Petroleum oils and oils from bituminous minerals".

Table A.3 : Correlation between Chained and Fixed-base Indices (in logarithms)

\begin{tabular}{|c|c|c|c|c|}
\hline \multicolumn{5}{|c|}{$\begin{array}{l}\text { Spearman Correlation Coefficients (1835 observations) } \\
\text { In brackets, Prob }>|r| \text { under } H_{0} \text { : No correlation }\end{array}$} \\
\hline & Laspeyres & Paasche & Tornqvist & Fisher \\
\hline \multirow[t]{2}{*}{ Chained Tornqvist } & 0.664 & 0.668 & 0.726 & 0.721 \\
\hline & $(\leq .001)$ & $(\leq .001)$ & $(\leq .001)$ & $(\leq .001)$ \\
\hline \multirow[t]{2}{*}{ Chained Fisher } & 0.652 & 0.652 & 0.708 & 0.704 \\
\hline & $(\leq .001)$ & $(\leq .001)$ & $(\leq .001)$ & $(\leq .001)$ \\
\hline
\end{tabular}




\section{LIST OF WORKING PAPERS RELEASED BY CEPII ${ }^{1}$}

No

Title

2008-09 Base de données CHELEM - Commerce international du CEPII

2008-08 The Brain Drain between Knowledge Based Economies: the European Human Capital Outflows to the US

2008-07 Currency Misalignments and Exchange Rate Regimes in Emerging and Developing Countries

2008-06 The Euro and the Intensive and Extensive Margins of Trade: Evidence from French Firm Level Data

2008-05 On the Influence of Oil Prices on Economic Activity and Other Macroeconomic and Financial Variables

2008-04 An Impact Study of the EU-ACP Economic Partnership Agreements (EPAs) in the Six ACP Regions

2008-03 The Brave New World of Cross-Regionalism

2008-02 Equilibrium Exchange Rates: a Guidebook for the Euro-Dollar Rate

2008-01 How Robust are Estimated Equilibrium Exchange Rates? A Panel BEER Approach

2007-24 Testing the Finance-Growth Link: Is there a Difference between Developed and Developing Countries?

2007-23 Labor Migration: Macoeconomic and Demographic outlook for Europe and Neighborhood Regions

2007-22 Economic Geography, Spatial Dependence and Income Inequality in China

2007-21 Does FDI in Manufacturing Cause FDI in Business Services? Evidence from French Firm-Level Data

\section{Authors}

A. de Saint Vaulry

A. Tritah

V. Coudert

\& C. Couharde

A. Berthou

\& L. Fontagné

F. Lescaroux

\& V. Mignon

L. Fontagné,

D. Laborde

\& C. Mitaritonna

A. Tovias

A. Bénassy-Quéré,

S. Béreau

\& V. Mignon

A. Bénassy-Quéré,

S. Béreau

\& V. Mignon

G. Dufrénot,

V. Mignon

\& A. Péguin-Feissolle

V. Borgy

\& X. Chojnicki

L. Hering

\& S. Poncet

B. Nefussi

\& C. Schwellnus

\footnotetext{
${ }^{1}$ Working papers are circulated free of charge as far as stocks are available; thank you to send your request to CEPII, Sylvie Hurion, 9, rue Georges-Pitard, 75015 Paris, or by fax : (33) 0153685504 or by e-mail Hurion@cepii.fr. Also available on: IIwww.cepii.fr. Working papers with* are out of print. They can nevertheless be consulted and downloaded from this website.
} 
2007-20 Bilateral Trade of Cultural Goods

2007-19 China and India in International Trade: from Laggards to Leaders?

2007-18 How Remote is the Offshoring Threat

2007-17 Costs and Benefits of Euro Membership: a Counterfactual Analysis

2007-16 Location Decisions and Minimum Wages

2007-15 MIRAGE, Updated Version of the Model for Trade Policy Analysis Focus on Agriculture and Dynamics

2007-14 Mondialisation des services de la mesure à l'analyse

2007-13 How are wages set in Beijing?

2007-12 IMF Quotas at Year 2030

2007-11 FDI and Credit Constraints: Firm Level Evidence in China

2007-10 Fiscal Policy in Real Time

2007-09 Global Ageing and Macroeconomic Consequences of Demographic Uncertainty in a Multi-regional Model

2007-08 The Effect of Domestic Regulation on Services Trade Revisited

2007-07 The Location of Domestic and Foreign Production Affiliates by French Multinational Firms

2007-06 Specialisation across Varieties within Products and North-South Competition

2007-05 Trade Costs and the Home Market Effect
A.C. Disdier,

S.H.T. Tai,

L. Fontagné

\& T. Mayer

F. Lemoine \& D. Ünal-Kesenci

K. Head, T. Mayer \& J. Ries

E. Dubois, J. Héricourt \& V. Mignon

I. Méjean \& L. Patureau

Y. Decreux \& H. Valin

I. Bendisoun \& D. Ünal-Kesenci

J. De Sousa \& S. Poncet

A. Bénassy-Quéré, S. Béreau,

Y. Decreux, C. Gouel \& S. Poncet

J. Héricourt \& S. Poncet

J. Cimadomo

J. Alho \& V. Borgy

C. Schwellnus

T. Mayer, I. Méjean \& B. Nefussi

L. Fontagné, G. Gaulier \& S. Zignago M. Crozet \& F. Trionfetti 


\section{CEPII \\ DOCUMENTS DE TRAVAIL / WORKING PAPERS}

Si vous souhaitez recevoir des Documents de travail, merci de remplir le coupon-réponse ci-joint et de le retourner à :

Should you wish to receive copies of the CEPII's Working papers, just fill the reply card and return it to:

Sylvie HURION - Publications

CEPII - 9, rue Georges-Pitard - 75740 Paris - Fax : (33) 1.53.68.55.04

sylvie.hurion@cepii.fr

M./Mme / Mr./Mrs

Nom-Prénom / Name-First name

Titre / Title

Service / Department

Organisme / Organisation

Adresse / Address.

Ville \& CP / City \& post code.

Pays / Country...... Tél.

Your e-mail

Désire recevoir les Document de travail du CEPII $n^{\circ}$ :

Wish to receive the CEPII's Working Papers No:

Souhaite être placé sur la liste de diffusion permanente (pour les bibliothèques)

Wish to be placed on the standing mailing list (for Libraries). 
